\title{
HUBUNGAN HUKUM PEKERJA DAN KEBERLAKUAN PERATURAN PERUSAHAAN DALAM PERUSAHAAN KONGLOMERASI
}

\author{
Windi Afdal ${ }^{1}$ \\ Carina $\operatorname{Tan}^{2}$
}

\begin{abstract}
This thesis reviewed about the legal relations of workers and the enactment of company regulations in conglomeration companies if contract of the workers in the parent company are transferred to other subsidiaries which are conglomeration companies with equal ownership or the existence of a very special relationship. The role of company regulations is very important in resolving industrial disputes where the existence of company regulations in every company in a conglomeration company will guarantee the rights between workers and the company in writing.

In this thesis, Researcher finds that conglomeration companies include PT. AG, PT. TMI, PT. GCS and PT. KTI, that the Company Regulations are only owned by the First Company, which is PT. AG, but not owned by others. Then Researcher found out that the employees which status is PWKTT who had worked 3 years in the First Company were transferred by the management of the conglomeration company to the Next Company to avoid the status of PKWT.
\end{abstract}

Keywords: Corporations, Company Regulations, Work Agreements, Conglomeration Companies

\section{A. Latar Belakang}

Perusahaan didirikan oleh Pengusaha bertujuan untuk mencari keuntungan. Dalam menjalankan usahanya, Pengusaha membutuhkan pekerja untuk mengelola perusahaan yang didirikannya agar menghasilkan profit yang lebih, tidak hanya Pengusaha yang membutuhkan Pekerja, namun sebaliknya Pekerja juga membutuhkan pekerjaan dari Pengusaha untuk mendapatkan upah/gaji.

Seiring perkembangan bisnis, pada prakteknya kebanyakan Pengusaha membentuk banyak perusahaan untuk mendapatkan keuntungan yang berlipat ganda. Lebih tepatnya pembentukkan perusahaan anak ini disebut sebagai perusahaan konglomerasi. Sampai saat ini belum diatur peraturan yang melarang perusahaan yang dengan sengaja memindahkan Perjanjian Kerja atau Kontrak Kerja karyawan yang sudah 3 tahun bekerja kepada anak perusahaan dengan kepemilikan saham yang sama namun dengan Perseroan yang berbeda tetapi tetap bekerja kepada perusahaan yang sebelumnya.

\footnotetext{
${ }^{1}$ Fakultas Hukum Universitas Internasional Batam

${ }^{2}$ Fakultas Hukum Universitas Internasional Batam
} 
Peneliti meneliti peristiwa tersebut pada Perusahaan Konglomeraasi yaitu PT. AG, PT. TMI, PT. GCS dan PT. KTI

Keempat perusahaan ini merupakan Perusahaan Konglomerasi yang mana Peraturan Perusahaan hanya dimiliki oleh perusahaan yang pertama kali didirikan yaitu PT. AG, sedangkan perusahaan lain tidak memiliki Peraturan Perusahaan. Sebagaimana dalam ketentuan bahwa "Pengusaha yang mempekerjakan pekerja/buruh sekurang-kurangnya 10 peraturan perusahaan yang mulai berlaku setelah disahkan oleh Menteri atau pejabat yang ditunjuk". Manajemen perusahaan yang diteliti oleh Peneliti menentukan Peraturan Perusahaan yang dimiliki oleh Perusahaan yang pertama kali didirikan diberlakukan bagi seluruh anak perusahaan, hal ini disebabkan karena perusahaan konglomerasi tersebut merupakan Single Economy Entity.

Konflik yang akan terjadi adalah apabila dalam sebuah perusahaan tidak memiliki Peraturan Perusahaan akan berdampak bagi karyawan maupun perusahaan itu sendiri. Konflik yang dimaksud adalah apabila terjadi perselisihan dalam hubungan industrial, maka karyawan maupun perusahaan kehilangan sebuah pegangan yang dapat mengatasi perselisihan tersebut. Di dalam Peraturan Perusahaan akan tertulis solusi penyelesaian sengketa dalam hubungan industrial yakni penyelesaian sengketa dalam pengadilan maupun diluar pengadilan (penyelesaian melalui abritrase, mediasi, bipatrit).

Berdasarkan apa yang telah Peneliti paparkan di atas, maka Peneliti tertarik untuk membuat jurnal dengan judul "Hubungan Hukum Pekerja dan Keberlakuan Peraturan Perusahaan dalam Perusahaan Konglomerasi” dengan rumusan masalah yaitu: Pertama, Bagaimana hubungan hukum pekerja dalam suatu perusahaan konglomerasi? Kedua, Bagaimana pemberlakuan Peraturan Perusahaan dalam suatu perusahaan konglomerasi?

\section{B. Metode Penelitian}

Pada jurnal ini, Peneliti akan mengaplikasikan Penelitan Empiris untuk mendapatkan data dari lapangan sehingga dapat membagikan kepada Pembaca akan pengalaman yang dialami oleh responden yang dipilih oleh Peneliti.

Sesuai dengan topik jurnal yang Peneliti pilih, Peneliti akan menggunakan data primer yang sebagai bahan utama, data sekunder sebagai bahan untuk menganalis bahan hukum primer, dan menggunakan bahan hukum tersier sebagai pendukung kedua bahan hukum tersebut.

Bedasarkan pengertian jenis data yang telah dijelaskan diatas, maka Peneliti akan menggunakan jenis data primer sebagai data utama dan data sekunder sebagai data pendukung. Dimana data primer meliputi wawancara dengan narasumber yang akan membantu Peneliti dalam menelaah data, sedangkan Data sekunder meliputi: Pertama, Bahan Hukum 
Primer, yaitu: Undang-Undang Nomor 13 Tahun 2003 Tentang Ketenagakerjaan, Kitab Undang- Undang Hukum Perdata (KUHPerdata), Undang-Undang Nomor 40 Tahun 2007 Tentang Perseroan Terbatas, Peraturan Menteri Tenaga Kerja dan Transmigrasi Nomor PER.16/MEN/XI/2011 Tentang Tata Cara Pembuatan Dan Pengesahan Peraturan Perusahaan Serta Pembuatan dan Pendaftaran Perjanjian Kerja Bersama. Kedua, Bahan Hukum Sekunder, yaitu: jurnal hukum, karya tulis kalangan hukum, dan pendapat hukum, ketiga, Bahan Hukum Tersier adalah Kamus Besar Bahasa Indonesia.

Dalam penelitian jurnal ini, Peneliti menggunakan 3 metode pengumpulan tersebut, yaitu: teknik pengumpulan data wawancara, kuesioner dan studi kepustakaan. Berikut ini adalah teknik pengumpulan data yang akan dipakai oleh Peneliti dalam rangka penelitian:

1. Wawancara

Wawancara atau biasanya disebut dengan interview merupakan percakapan yang dilakukan oleh dua pihak atau lebih untuk memperoleh informasi yang lebih akurat. Dalam melakukan wawancara, Peneliti menyiapkan beberapa pertanyaan kepada Direktur dan HRD dimana Peneliti meneliti untuk mendapatkan jawaban.

2. Angket (kuesioner)

Teknik ini dilakukan dengan cara membuat daftar pertanyaan dalam bentuk hardcopy, kemudian dibagikan kepada responden untuk diisi. Namun pada zaman modern saat ini, sudah bisa menggunakan google drive/penyimpanan online atau website di internet dibagikan dalam bentuk link untuk diisi. Akan tetapi responden Peneliti tidak semuanya pandai membaca maupun menulis, oleh sebab itu

Peneliti tidak menggunakan googledrive melainkan dalam bentuk hardcopy dan dibagikan kepada responden. Peneliti menyiapkan berbagai pertanyaan kepada responden yakni masing-masng 30 karyawan dari 4 perusahaan, yaitu PT. AG sebaga Perusahaan Pertama, PT. TMI, PT. GCS dan PT. KTI sebagai Perusahaan selanjutnya yang didirikan.

3. Studi Kepustakaan

Teknik pengumpulan data dalam bentuk studi kepustakaan dilakukan dengan mengumpulkan data melalui bahan-bahan hukum seperti literatur hukum, jurnal, maupun doktrin hukum. baik dokumen tertulis, foto-foto, gambar, maupun dokumen elektronik yang dapat mendukung dalam proses penulisan. Selain melalui Wawancara dan Kuesioner, Peneliti akan menggunakan Teknik Pengumpulan Studi Kepustakaan untuk mendukung data yang telah didapatkan. 
Dalam penelitian ini, Peneliti akan menggunakan metode analisis deskriptif kualitatif dimana Peneliti menelaah permasalahan data yang diperoleh dari hasil lapangan dengan menggambarkan/menyelidiki fenomena yang ada di sosial, kemudian melakukan tindakan kualitatif memahami fenomena sosial yang terjadi dan menjelaskan fenomena tersebut dan dikaji berdasarkan teori kedalam Penelitian Jurnal ini.

\section{Hasil Penelitian dan Pembahasan}

Dalam penyebaran kuesioner kepada 4 perusahaan dengan menyebarkan sebanyak 30 kuesioner kepada masing-masing perusahaan yang diteliti oleh Peneliti. Setiap kuesioner diberikan kepada responden dan diharapkan agar responden dapat mengisi pernyataan-pernyataan yang diajukan pada kuesioner sesuai dengan keadaan sebenarnya.

Dilihat dari keseluruhan pengambilan data kuesonier maupun wawancara dapat ditarik kesimpulan bahwa perusahaan dalam membuat Peraturan Perusahaan sudah sesuai dengan peraturan perundangundangan, namun dalam mengalihkan kontrak kerja karyawan pada Perusahaan Selanjutnya yang didirikan tersebut tidak merupakan kesalahan perusahaan juga. Karena belum ada peraturan yang mengatur perihal mutasi kontrak kerja merupakan suatu hal yang melanggar.

\section{Hubungan Hukum Pekerja dalam Suatu Perusahaan Konglomerasi}

Setiap Perusahaan Konglomerasi menjalankan fungsi sebagai kesatuan ekonomi. Perusahaan Pertama bertindak sebagai pimpinan sentral yang mengendalikan dan mensinergikan kegiatan bisnis Perusahaan dibawahnya dalam suatu kesatuan ekonomi yang secara kolektif mendukung kepentingan bisnis konglomerasi.

Kepentingan pekerja atau buruh pun dapat dirugikan oleh fakta bahwa perusahaan di tempat mereka bekerja adalah merupakan perusahaan bagian dari satu konglomerasi. Dalam keadaan para pekerja dapat pindahkan oleh suatu perusahaan konglomerasi kepada perusahaan konglomerasi lain.

Kepemilikan atas Perusahaan setelah didirikannya Perusahaan Pertama dalam jumlah signifikan memberikan kewenangan kepada Perusahaan Pertama untuk bertindak sebagai pimpinan sentral yang mengendalikan Perusahaan Selanjutnya yang didirikan untuk bertindak sebagai pimpinan sentral yang mengendalikan Perusahaan Selanjutnya yang didirikan sebagai kesatuan manajemen. Salah satu fungsi kepemilikan saham Perusahaan Pertama yang didirikan terhadap Perusahaan selanjutnya adalah zeggenschapsfuntie, artinya kepemilikan Perusahaan Pertama untuk mengendalikan Perusahaan dibawahnya melalui berbagai mekanisme pengendalian yang ada, seperti RUPS untuk mendukung belenggingsfuntie sebagai kesatuan ekonomi. 
Meskipun Perusahaan Konglomerasi merupakan satu kesatuan, namun ketiga perusahaan merupakan entitas yang berbeda. Oleh karena terjadinya pengalihan karyawan dari perusahaan yang Pertama kepada Perusahaan Selanjutnya, secara hukum perjanjian antara karyawan dengan Perusahaan yang pertama kali dikontrak berakhir atau putus sehingga tidak ada keterkaitan apapun lagi terhadap perusahaan pertama dimana dia dikontrak pertama kali.

Peneliti memberikan penjelasan keterkaitan permasalahan mengenai pengalihan kontrak kerja karyawan yang sudah 3 tahun bekerja, dialihkan kepada perusahaan lainnya yang merupakan Perusahaan Konglomerasi dengan Perjanjian Kerja dalam bentuk tertulis yang didalamya memuat beberapa hal merujuk pada pasal 54 ayat (1) Undang-Undang Nomor 13 Tahun 2003, yaitu:

a. nama, alamat perusahaan dan jenis usaha;

b. nama, jenis kelamin, umur dan alamat pekerja/buruh;

c. jabatan atau jenis pekerjaan;

d. tempat pekerjaan;

e. besarnya upah dan cara pembayarannya;

f. syarat-syarat kerja yang memuat hak dan kewajiban pengusaha dan pekerja/buruh;

g. mulai dan jangka waktu berlakunya perjanjian kerja;

h. tempat dan tanggal perjanjian kerja dibuat; dan

i. tanda tangan para pihak dalam perjanjian kerja."

Ketentuan jelas dikatakan bahwa Perjanjian Kerja harus memuat Nama, Alamat Perusahaan dan Jenis Usaha. Oleh karena itu, Perjanjian kerja yang dialihkan dari satu Perusahaan ke Perusahaan lain tidak berlaku lagi karena terjadinya peralihan pemberi kerja karena berbeda nama badan hukumnya. Berbicara mengenai masa kerja dihitung lagi dari 0 (nol) sejak karyawan menanda-tangani kontrak pada perusahaan kedua dan tidak ada pesangon bagi karyawan yang dialihkan/ditransfer.

Konflik pada penelitian jurnal ini adalah manajemen perusahaan hanya memperkerjakan karyawan maksimal 3 tahun ditempatkan pada Perusahaan Pertama. Sehingga ketika pembaruan kontrak, Karyawan tersebut akan dipindahkan/dialihkan atas nama perusahaan yang lainnya demi menghindar status PKWTT. Kemudian, tidak ada ketentuan larangan hukum mengenai tindakan dalam memindahkan kontrak karyawan secara sengaja yang menyebabkan Karyawan kehilangan status PKWTT. 
Sehingga sampai saat ini, Perusahaan yang diteliti oleh Peneliti tidak memiliki karyawan PKWTT atau disebut dengan Karyawan Permanen. Hal ini juga tidak menjadi kewajiban bagi pengusaha untuk membuat kontrak permanen bagi karyawan PKWTT yang sudah 3 tahun bekerja, sehingga Perusahaan yang diteliti oleh Peneliti secara langsung memindahkan kontrak kerja karyawan yang sudah 3 tahun bekerja kepada Perusahaan lain untuk menghindar tanggung jawab yang harus dilaksanakan oleh Pengusaha setelah karyawan tersebut berubah dari PKWT menjadi PKWTT.

2. Ketentuan pemberlakuan Peraturan Perusahaan dalam suatu Perusahaan Konglomerasi

Peraturan Perundang-undangan tetap mememiliki keterkaitan mengenai kegiatan bisnis sesuai dengan perkembangan dan dominasi Perusahaan konglomerasi. Dengan mempunyai saham dalam perseroan lain akan dilegitimasi oleh suatu perseroan menurut Undang-Undang Nomor 40 Tahun 2007. Untuk mendirikan suatu perseroan telah di tentukan sebagaimana dalam Pasal 7 ayat (1) Undang-Undang Nomor 40 Tahun 2007. Badan hukum Indonesia, warga Indonesia ataupun orang perorangan merupakan "Orang" sesuai dengan Memori penjelasan Pasal 7 ayat (1) Undang-Undang Nomor 40 Tahun 2007. Munculnya keterlibatan 2 perseoran dengan kepemilikan saham akibat dari pendirian suatu perseroan yang menimbulkan perbuatan hukum suatu badan hukum.

Perseroan Terbatas atau disingkat dengan PT merupakan suatu wujud perusahaan dikatakan sebagai badan usaha diatur dalam Undang Undang Nomor 40 Tahun 2007 tentang Perseroan Terbatas "Pasal 1 ayat (1) menegaskan Perseroan Terbatas adalah badan hukum yang merupakan persekutuan modal, didirikan berdasarkan perjanjian, melakukan kegiatan usaha dengan modal dasar yang seluruhnya terbagi dalam saham dan memenuhi persyaratan yang ditetapkan dalam Undang-Undang ini serta peraturan pelaksanaannya".

Bentuk sistematika perseroan tunggal disesuaikan dengan hukum perseroan, oleh sebab itu untuk perseroan yang berbadan hukum mandiri memiliki prinsip-prinsip hukum sebagai dasar perseroan terbatas yang meliputi pengesahan badan hukum, kemandirian badan hukum perseroan terbatas atau separate legal entity, dan limited liability. Pengesahan status badan hukum memberikan legitimasi kepada suatu badan usaha untuk menyandang status badan hukum perseroan, sebagaimana ketentuan Pasal 1 angka (1)

Undang-Undang Nomor 40 Tahun 2007 yang menyatakan bahwa Perseroan Terbatas adalah badan hukum. ${ }^{3}$

\footnotetext{
${ }^{3}$ Sulistiowati, Tanggung Jawab Hukum Pada Perusahaan Grup Di Indonesia, ed. Novietha I.
} 
Undang-undang Dasar Negara Republik Indonesia 1945 pada Pasal 1 ayat 3 menentukan bahwa Negara Indonesia adalah Negara Hukum. Hal ini mengandung konsekuensi bahwa setiap tindakan pemerintah haruslah berdasarkan pada hokum. Semua orang tanpa kecuali harus tunduk dan taat pada hukum, hanya hukumlah yang berkuasa dalam Negara tersebut.

Dalam bidang Ketenagakerjaan, Pemberi Kerja (Pengusaha, Perseroan, CV, badan hukum atau dengan istilah yang lainnya) melalui bagian manajemen / SDM wajib menaati dan melaksanakan Peraturan Perundang-undangan yang mengatur tentang Ketenagakerjaan Undang-undang Nomor 13 Tahun 2013 tentang Ketenagakerjaan, Peraturan Menteri Tenaga Kerja dan Transmigrasi serta Keputusan Menteri Tenaga Kerja dan Transmigrasi menjadi dasar dan acuan dalam pengelolaan ketenagakerjaan di negara Indonesia. ${ }^{4}$

Berdasarkan pengertian tersebut maka untuk dapat disebut sebagai perusahaan PT menurut undang-undang harus memenuhi unsur- unsur:

a. Berbentuk badan hukum, yang merupakan persekutuan modal;

b. Didirikan atas dasar perjanjian;

c. Melakukan kegiatan usaha;

d. Modalnya terbagi saham-saham;

e. Memenuhi persyaratan yang ditetapkan dalam undang-undang ${ }^{5}$

Keberadaan dan pengakuan yuridis terhadap perusahaan Konglomerasi menjadi salah satu perdebatan yang telah berlangsung lama serta melibatkan berbagai wilayah yuridiksi perdebatan yang berbeda perbedaan pendapat mengenai pengertian yuridis Perusahaan Konglomerasi bersumber dari belum adanya pengkauan yuridis terhadap status badan hukum.

Belum adanya pengakuan yuridis terhadap status badan hukum dari Perusahaan Konglomerasi menyebabkan peraturan perundangundangan tidak mengatur mengenai kontruksi penrusahaan Konglomerasi. Sebaliknya, perundangan- undangan masih menggunakan pendekatan perseroan tunggal dari peroran-perseroan yang menjadi konstituen Perusahaan Konglomerasi, sehingga peraturan perundang-undangan masih mempertahankan pengakuan yuridis formal dari status badan masing-masing perusahaan.

Sallama (Jakarta: Penerbit Erlangga, 2013).

${ }^{4}$ Furywardhana Firdaus, "Permasalahan Tentang Kompensasi Bagi Pekerja Pimpinan Yang Bekerja Di Lapangan Operasi Pada PT. ABC," Arena Hukum 8, no. 1 (April 1, 2015): 92-107.

${ }^{5}$ Natun Julio Thimotius Kapitan Smaud, "Status Kepemilikan Anak Perusahaan Bumn" 12, no. 1 (2019). 
Hubungan perusahaan yang pertama didirikan dengan beberapa perusahaan-perusahaan lain atau disebut sebagai Perusahaan Konglomerasi tetap merupakan status badan hukum yang terpisah atau merupakan Perusahaan yang mandiri sehingga secara yuridis meskipun merupakan satu kesatuan ekonomi, perusahaan-perusahaan yang didirikan setelah perusahaan pertama tersebut tunduk dibawah kendali perusahaan yang pertama kali didirikan.

Apabila dibandingkan dengan hukum perseroan terbatas, hukum Perusahaan Konglomerasi menangani gejala khusus dari tersusunnya perusahaan-perusahaan yang secara yuridis mandiri dalam suatu susunan yang era tantara satu sama lain, sehingga dari sudut pandang ekonomi dipandang sebagai suatu kesatuan yang berada dibawah pimpinan sentral. Perusahaan Konglomerasi merupakan suatu ekonomi yang tersusun dari perusahaan-perusahaan berbadan hukum mandiri yang dipandang sebagai Perusahaan Konglomerasi.

Sesuai dengan peruntukan hukum perseroan sebagai kerangka pengaturan bagi perseroan tunggal, terhadap Perusahaan Konglomerasi yang terbentuk perseoran terbatas berlaku prinsip hukum yang sama dengan perseroan tunggal, yaitu perseroan sebagai subjek hukum mandiri dan berlakunya limited liability pada pemegang saham. Hukum perseroan sebagai kerangka pengaturan perseroan tunggal tidaklah mengatur konstruksi Perusahaan Konglomerasi, tetapi mengatur keterkaitan antara Perusahaan yang pertama didirikan dengan Perusahaan- perusahaan lain yang didirikan sebagai hubungan di antara badan hukum mandiri.

Kerangka pengaturan mengenai Perusahaan Konglomerasi yang menggunakan pendekatan perseroan tunggal menimbulkan kontradiksi dengan realitas bisnis yang ditandai oleh adanya pengendalian Perusahaan Pertama terhadap Perusahaan Selanjutnya. Penyebab timbulnya kontradiksi ini adalah legitimasi peraturan perundang-undangan terhadap munculnya realitas kelembagaan Perusahaan Konglomerasi. Peraturan perundang-undangan mengizinkan suatu perseroan melakukan perbuatan hukum untuk memiliki maupun memperoleh saham pada perseroan lain, baik melalui pendirian perseroan lain, pengambilalihan saham perusahaan lain, maupun pemisahan usaha.

Kepemilikan saham suatu perseroan pada perseroan lain menjadi sebab timbulnya keterkaitan Perusahaan Pertama dan Perusahaan Selanjutnya, sehingga Perusahaan Pertama memiliki kekuasaan untuk bertindak sebagai pimpinan sentral yang mengendalikan dan mengoordinasikan Perusahaan Selanjutnya yang didirikan dalam mendukung tercapainya tujuan kolektif Perusahaan Konglomerasi sebagai kesatuan ekomomi. 
Perusahaan Pertama didirikan memiliki pengertian akan badan yang memiliki saham suatu perusahaan yang bertujuan untuk memiliki saham dalam satu atau lebih perusahaan lain dan/atau mengatur satu atau lebih perusahaan lain tersebut. Peraturan Perusahaan merupakan Peraturan yang dibuat secara tertulis yang mengatur tentang syarat kerja, tata tertib perusahaan serta hak dan kewajiban Pekerja maupun Pengusaha. Selain mengatur tentang tata tertib perusahaan, dalam pembuatan Peraturan Perusahaan juga mempersyarakatkan bagi Perusahaan yang mempekerjakan Karyawan 10 (sepuluh) orang sesuai Pasal 108 ayat (1) UndangUndang Nomor 13 Tahun 2003. Apabila suatu perusahaan memiliki Perjanjian Kerja Bersama, maka Peraturan Perusahaan tidak berlaku lagi, karena Perjanjian Kerja Bersama telah mengatur tata tertib perusahaan sebagaimana dengan yang diatur dalam Peraturan Perusahaan. Sesuai dengan pengertian Peraturan yang telah diberikan sebelumnya, Maka Peraturan Perusahaan diwajibkan bagi perusahaan yang merekrut karyawan lebih dari 10 orang supaya kepentingan masing- masing pihak yaitu hak dan kewajiban tidak dirugikan.

Perusahaan Pertama yang didirikan memiliki kewenangan untuk menjadi pimpinan sentral yang mengendalikan dan mengoordinasikan Perusahaan Selanjutnya yang didirikan dalam suatu kesatuan atau pengaruh yang bersifat menentukan. Pelaksanaan pengaruh dalam Perusahaan Pertama yang didirikan dapat bersifat mengurangi hak atau mendominasi hak perusahaan lain. Atas kewenangan Perusahaan Pertama yang didirikan untuk megendalikan Perusahaan selanjutnya yang didirikan setelah Perusaahan Pertama, maka Perusahaan Pertama yang didirikan dianggap menjalankan fungsi sebagai holding company.

Perusahaan Konglomerasi tidaklah mengacu kepada suatu badan hukum, tetapi kepada suatu kesatuan ekonomi dari badan hukum Perusahaan Pertama dan Perusahaan Selanjutnya (yang didirikan) dan yang dikonsolidasikan dalam laporan keuangan antara dua atau lebih Perusahaan tersebut. Terhadap Perusahaan Konglomerasi yang berbentuk perseroan, undang-undang Perseroan terbatas maupun peraturan perundang-undangan lain masih mempertahankan pengakuan yuridis terhadap status badan hukum Perusahaan Konglomerasi sebagai subjek hukum mandiri.

Permasalahan hukum mengenai tanggung jawab pada Perusahaan Konglomerasi berawal dari pemis yang menekankan pada prinsip hukum perseroan sebagai legal action. Prinsip hukum ini dikembangkan dan didesain untuk perusahaan tunggal tetapi tidak ditujukan bagi Perusahaan Konglomerasi. Pengakuan yuridis terhadap kemandirian yuridis terhadap badan hukum perseroan ini menjadi model ideal bagi badan hukum yang terdiri dari para pemegang saham dan direksi yang menjalankan kegiatan usaha untuk 
kepentingan bisnis perseroan yang bersangkutan. Pada sisi lain, setiap perusahaan-perusahaan memiliki tanggung jawab dan menanggung atas seluruh tindakan dan kesalahan yang dijalankan dalam relasi Perusahaan Konglomerasi.

Pada prinsipnya, dalam interaksinya dengan pihak ketiga, sesama anggota Perusahaan Konglomerasi tidak mempunyai kepentingan dengan hak dan kewajiban dari anggota perusahaan lainnya, sehingga tidak dapat bertanggung jawab terhadap pihak ketiga dan juga tidak memperoleh hak dari mereka berdasarkan hubungan hukum antara salah satu perusahaan didalam concern dengan pihak luar ataupun pihak ketiga.

Belum adanya peraturan perundang-undangan yang mengatur secara khusus Perusahaan Konglomerasi menyebabkan kerangka pengaturan terhadap perseroan-perseroan yang tergabung dalam suatu Perusahaan Konglomerasi yang masih menggunakan pendekatan perseroan tunggal. Hukum perseroan memandang keterkaitan Perusahaan-perusahaan dalam Perusahaan Konglomerasi sebagai hubungan khusus yang berbadan hukum mandiri. Meskipun tunduk kepada Perusahaan Pertama, Perusahaan Selanjutnya tersebut berhak melakukan perbuatan hukum sendiri, sedangkan Perusahaan Pertama tidak bertanggung jawab atas perbuatan hukum Perusahaan Selanjutnya.

Peraturan Perusahaan yang dimiliki oleh Perusahaan Pertama tersebut tidak diketahui oleh banyak karyawan, sehingga mereka tidak mengetahui bahwa Peraturan Perusahaan tersebut hanya berlaku bagi mereka yang mengikatkan diri dengan Perusahaan Pertama dan tidak berlaku bagi mereka yang tidak mengikatkan diri dengan perusahaan Pertama yang dikontrak.

Dalam Pengesahan Peraturan Perusahaan tidak dibutuhkan persetujuan dari Serikat Pekerja, namun hanya pertimbangan saran dari Wakil Pekerja yang dipilih oleh karyawan di perusahaan tersebut dan berbeda dengan Perjanjian Kerja Bersama yang membutuhkan persetujuan dari antara Serikat Pekerja dengan perusahaan. Drujuk pada Pasal 32 Undang-Undang Nomor 13 Tahun 2003 bahwa:

a. Penempatan tenaga kerja dilaksanakan berdasarkan asas terbuka, bebas, obyektif, serta adil, dan setara tanpa diskriminasi.

b. Penempatan tenaga kerja diarahkan untuk menempatkan tenaga kerja pada jabatan yang tepat sesuai dengan keahlian, keterampilan, bakat, minat, dan kemampuan dengan memperhatikan harkat, martabat, hak asasi, dan perlindungan hukum.

c. Penempatan tenaga kerja dilaksanakan dengan memperhatikan pemerataan kesempatan kerja dan penyediaan tenaga kerja sesuai 
dengan kebutuhan program nasional dan daerah

Sehingga dapat dipahami bahwa apabila satu Peraturan Perusahaan yang difungsikan bagi seluruh perusahaan konglomerasi, maka ketentuan dalam isi peraturan tersebut tidak belaku lagi bagi perusahaan yang lainnya. Namun ada satu pengecualiannya lainnya yaitu, Apabila:

1. Perusahaan membuat Peraturan Perusahaan turunan yang berlaku khusus bagi karyawan di masing- masing Perusahaan sesuai dengan kondisi masing-masing Perusahaan.

2. Perjanjian Pengalihan. Perjanjian ini dibuat agar hak karyawan tidak dikurangi. Namun harus ada persetujuan Pekerja dan Perusahaan. Perjanjian ini sangat penting demi kepastian hukum bagi karyawan, karena masa kerja sangat menentukan hak-hak karyawan seperti uang pesangon, uang penghargaan masa kerja, uang penggantian hak dan uang pisah.

Tergabungnnya beberapa perusahaan yang disebut sebagai Perusahaan Konglomerasi tidaklah menghapuskan pengakuan yuridis terhadap status hukum masing-masing Perusahaan. Perusahaan Pertama dan Perusahaan-Perusahaaan Selanjutnya didirikan yang berbentuk perseroan tetap diakui sebagai subjek hukum mandiri. Perusahaan Pertama disebut sebagai pemegang saham sehingga perusahaan tidak bertanggung jawab secara pribadi atas perikatan yang dibuat oleh Perusahaan Selanjutnya yang didirikan. Dengan demikian, Perusahaan Konglomerasi tidak bertanggung jawab atas perbuatan hokum Perusahaan Selanjutnya.

Berdasarkan teori yang peneliti gunakan yakni teori Korporasi Menurut Subekti dan Tjitrosudiro mengatakan bahwa "Yang dimaksud dengan korporasi (corporatie) adalah suatu perseroan yang merupakan badan hukum" dan menurut Utrech dan M. Soleh Djindang yang mengemukakan: "Korporasi adalah suatu gabungan orang dalam pergaulan hukum bertindak bersama-sama sebagai suatu subyek hukum tersendiri sebagai suatu personafikasi. Korporasi adalah badan hukum yang beranggota, tetapi mempunyai hak dan kewajiban tersendiri yang terpisah dari hak dan kewajiban anggota masing- masing".

Teori Korporasi yang dipaparkan oleh ahli tersebut dapat disimpulkan bahwa suatu badan yang dijalankan masing-masing memiliki hak dan kewajiban yang dipertanggungjawabkan oleh masing- masing perseroan. Sehingga dalam konteks penelitian Peneliti mengenai Perusahaan Konglomerasi adalah masing-masing perusahaan hanya bertanggung jawab kepada masing-masing karyawan yang mengikatkan diri kepada Perusahaan tersebut meskipun merupakan Single Economic Entity namun Perusahaan Selanjutnya adalah Entitas Hukum Mandiri, sehingga setiap 
Perusahaan yang telah didirikan wajib memiliki Peraturan Perusahaan sendiri yang mandiri.

Perusahan Konglomerasi yang diteliti oleh Peneliti yaitu Perusahaan Pertama, Kedua, Ketiga dan Keempat yakni PT. AG, PT.TMI, PT.GCS, PT. KTI tidak memiliki kaitan maupun hubungan secara hukum dalam hal hak dan kewajiban, dengan kata lain Perusahaan Pertama tidak bertanggung jawab pada Perusahaan Kedua, Ketiga dan Keempat ataupun sebaliknya. Oleh sebab itu, masing-masing perusahaan bertanggung jawab secara masing-masing dan tidak melibatkan pihak manapun termasuk Peraturan Perusahaan yang hanya dimiliki oleh Perusahaan Pertama tidak berlaku secara keseluruhan bagi Perusahaan Konglomerasi.

\section{Kesimpulan}

Bedasarkan hasil penelitian yang dilakukan oleh Penulis maka dapat disimpulkan bahwa:

1. Tidak ada larangan dalam peraturan perundang-undangan bahwa mengalihkan kontrak karyawan PKWT yang sudah bekerja selama 3 tahun kepada perusahaan yang lain untuk menghindar status PKWTT adalah melanggar hukum.

2. Pasal 3 ayat (1) Undang-Undang Nomor 40 tahun 2007 tentang Perseroan Terbatas, sebagai entitas yang terpisah dari pemiliknya. Dengan demikian merujuk pada ketentuan Undang-Undang Nomor 13 Tahun 2003 pasal 108 ayat (1) Perusahaan yang memiliki 10 karyawan wajib memiliki Peraturan Perusahaan. Dengan demikian, Anak Perusahaan wajib memiliki Peraturan Perusahaan mandiri. Namun dalam praktiknya, Perusahaan Kelompok yang diteliti tidak comply karena mereka tidak memiliki Peraturan Perusahaan mandiri pada masing- masing anak-anak perusahaan. 


\section{Daftar Pustaka}

\section{Buku:}

Budi, Santoso. Hukum Ketenagakerjaan Perjanjian Kerja Bersama. Edited by Tim UB Press. Malang: Tim UB Press, 2012.

Febri, Jaya. Perlindungan Hukum Pekerja Perempuan; Kajian Perbandingan Hukum Di Indonesia Dan Malaysia, 2014.

Much. Nurachmad. Peraturan Dan Perjanjian Dalam Perusahaan. Edited by Tim Medpress. Yogyakarta: Medpress Digital, 2013.

Rai, Widya. Hukum Perusahaan. Edited by Herman Sudrajat. Jakarta: Percetakan KBI, 2000.

Sulistiowati. (2013). Tanggung Jawab Hukum Pada Perusahaan Grup Di Indonesia (N. I. Sallama, ed.). Jakarta: Penerbit Erlangga.

Zainal, Asikin. Dasar-Dasar Hukum Perburuhan. Edited by Rahmatika. Jakarta: PT RajaGrafindo Persada, 2006.

\section{Peraturan Perundang-Undangan:}

Kitab Undang-Undang Hukum Perdata (KUHPerdata) Pasal 1320 KUHPerdata

Undang-Undang Nomor 21 Tahun 2000 Tentang Serikat Buruh

Undang-Undang Nomor 13 Tahun 2003 Tentang Hukum Ketenagakerjaan Undang-Undang Nomor 40 Tahun 2007 Tentang Perseroan Terbatas

Peraturan Menteri Tenaga Kerja dan Transmigrasi Nomor PER.16/MEN/XI/2011 Tentang Tata Cara Pembuatan Dan Pengesahan Peraturan Perusahaan Serta Pembuatan Dan Pendaftaran Perjanjian Kerja Bersama

\section{Jurnal:}

Afdal, Windi. "Korporasi Dalam Hukum Organisasi Bisnis Islam,” 2016.

Farah, Diba Nabilah. "Sistem Pengupahan Dalam Hubungan Kerja Di PT.Subur Antar Nusa Pekanbaru Menurut Undang- Undang Nomor 13 Tahun 2003 Tentang Ketenagakerjaan,” February 6, 2018.

Feri Yudha Niarto. "Perlindungan Hukum Terhadap Tenaga Kerja Wanita Indonesia Atas Tindak Pidana Kekerasan Dihubungkan Dengan Undang-Undang Nomor 39 Tahun 2004 Tentang Penempatan Dan Perlindungan TKI Di Luar Negeri,"

Firdaus, Furywardhana. "Permasalahan Tentang Kompensasi Bagi Pekerja Pimpinan Yang Bekerja Di Lapangan Operasi Pada PT. ABC." Arena Hukum 8, no. 1 (April 1, 2015): 92-107.

Grasia, Kurniati. "Konsekuensi Yuridis Perubahan Undang-Undang Perseroan Terbatas Terhadap Perseroan Yang Telah Memiliki Status Badan Hukum" 10, no. 23 (June 1, 2012).

Halim, Budi Wibowo. "Peraturan Perusahaan P.T.X Berkedudukan Di Jakarta,"

Miranda, Chairunnisa. "Pertanggunjawaban Perusahaan Induk Terhadap Perusahaan Anak Dalam Hal Terjadinya Pencemaran Dan/Atau 
Kerusakan Lingkungan Hidup.” USU Law Journal II, no. 2 (2013): 28-39.

Nurhamidah. "Pelaksanaan Pemberian Upah Lembur Bagi Para Pekerja PAda PT. Mitra Indah Sempurna Ditinjau Dari Undang-Undang No 13 Tahun 2003 Tentang Hukum Ketenagakerjaan," September 9, 2015.

Pratiwi, Dharnayanti Ni Made. "Hubungan Hukum Perusahaan Induk Berbentuk Perseroan Terbatas Dengan Anak Perusahaan Berbentuk Persekutuan Komanditer." Acta Comitas, April 3, 2017, 66.

Ratna, Yuliani. "Tanggung Jawab Induk Perusahaan Terhadap Anak Perusahaan Dalam Suatu Perusahaan Kelompok,"

Riyan, Sugandy. "Kewajiban Perusahaan Terhadap Pekerja,"

Situmorang Ruben. "Tinjauan Yuridis Tentang Perjanjian Kerja Bersama Ditinjau Dari Undang-Undang Nomor 13 Tahun 2003 Tentang Hukum Ketenagakerjaan,"

Smaud, Natun Julio Thimotius Kapitan. "Status Kepemilikan Anak Perusahaan Bumn” 12, no. 1 (2019).

Suhartoyo, Suhartoyo. "Penguatan Organisasi Buruh / Pekerja Sebagai Sarana Perlindungan Buruh" 1, no. 4 (December 5, 2018): 350-62.

Syahputra, Padang Rejeki. "Peranan Solidaritas Buruh Sumatera Utara (Sbsu) Dalam Memperjuangkan Hak-Hak Normatif Buruh Di PT Asia Karet Medan,"

Syamsi, Notarianul. "Perlindungan Hukum Terhadap Tenaga Kerja Wanita Di Indomaret Kota Pekanbaru Berdasarkan Undang- Undang Nomor 13 Tahun 2003 Tentang Ketenagakerjaan.,"

Ulfa, Amelia. "Perjanjian Kerja Dan Peraturan Perusahaan Serta Perjanjian Kerjasama Dengan Pemerintah,"

Wiratama. "Pelaksanaan Perjanjian Kerja Antara Karyawan Kontrak Dengan Rumah Sakit Permata Hati Duri Berdasarkan UndangUndang Nomor 13 Tahun 2003 Tentang Hukum Ketenagakerjaan," September 11, 2015.

Yuliani, Oesman. "Tinjauan Terhadap Perseroan Terbatas,"

Yuliyati. "Pelaksanaan Upah Minimum Kabupaten Bagi Pekerja Bongkar Muat Barang Di Pelabuhan Tanjung Buton Kabupaten Siak Menurut Undang-Undang Nomor 13 Tahun 2003 Tentang Ketenagakerjaan,” February 29, 2016.

\section{Bahan Lain:}

AINI MASKURO. "Pengertian Hukum Ketenagakerjaan - Hukum Corner." Accessed February 19, 2019. http://www.hukumcorner.com/pengertian-hukum-ketenagakerjaan/.

"Arti Kata Tenaga Kerja - Kamus Besar Bahasa Indonesia," https://kbbi.web.id/tenaga kerja. 